\title{
A Potential Mechanism for Immune Suppression by Beta-Adrenergic Receptor Stimulation following Traumatic Injury
}

\author{
Nicholas J. Shubin ${ }^{a}$ Tam N. Pham $^{b}$ Kristan Lea Staudenmayer ${ }^{c}$ \\ Brodie A. Parent ${ }^{\mathrm{b}}$ Qian Qiu ${ }^{\mathrm{d}}$ Grant E. O'Keefe ${ }^{\mathrm{e}}$ \\ a Seattle Children's Research Institute, Seattle Children's Hospital, Seattle, WA, USA; ${ }^{b}$ Department of Surgery, \\ University of Washington, Seattle, WA, USA; ' Department of Surgery, Stanford University, Stanford, CA, USA; \\ ${ }^{\mathrm{d} H}$ Harborview Injury Prevention and Research Center, Department of Pediatrics, University of Washington,

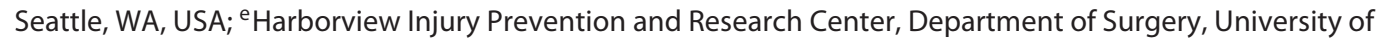 \\ Washington, Seattle, WA, USA
}

\section{Keywords}

Host defense $\cdot$ Immune response $\cdot$ Kinase $\cdot$ Phosphatase $\cdot$

Protein · Sepsis

\begin{abstract}
Background: $\beta$-Adrenergic agents suppress inflammation and may play an important role in posttraumatic infections. Mechanisms may include inhibition of MAP kinase signaling. We sought to determine whether MKP-1 contributed to catecholamine suppression of innate immunity and also wanted to know whether early catecholamine treatment after traumatic injury increases the risk of later nosocomial infection. Methods: We performed experiments using THP-1 cells and peripheral blood mononuclear cells from healthy individuals. We exposed cells to epinephrine and/or LPS and measured inflammatory gene transcription and MAP kinase activation. We inhibited MKP-1 activity to determine its role in catecholamine-induced immune suppression. Finally, we studied injured subjects to determine whether early catecholamine treatment was associated with nosocomial infection. Results: Epinephrine increases MKP-1 transcripts and protein and decreases LPS-induced $\mathrm{p} 38$ and JNK phosphorylation and TNF-a gene transcription. RNAi inhibition of
\end{abstract}

\section{KARGER}

() 2018 S. Karger AG, Basel

E-Mail karger@karger.com

www.karger.com/jin
MKP-1 at least partially restores LPS-induced TNF-a gene expression $(p=0.024)$. In the clinical cohort, subjects treated with $\beta$-adrenergic agents had an increased risk of ventilatorassociated pneumonia (aOR $=1.9 ; 95 \% \mathrm{Cl}=1.3-2.6)$ and bacteremia (aOR $=1.5 ; 95 \% \mathrm{Cl}=1.1-2.3)$. Conclusions: MKP-1 may have a role in catecholamine-induced suppression of innate immunity, and exogenous catecholamines might contribute to nosocomial infection risk.

(C) 2018 S. Karger AG, Basel

\section{Introduction}

Severe traumatic injury is often complicated by nosocomial infection and organ failure. Together, they contribute to prolonged ICU stays and, when shock is present, have high case-fatality rates $[1,2]$. For those who survive, quality of life may be poor [3].

We have observed that at the level of gene expression, markers of both innate and adaptive immunity are suppressed within $96 \mathrm{~h}$ of injury in trauma victims who subsequently develop bacteremia [1]. Some investigators have observed discordant changes in innate and adaptive immunity, reflecting the complexity of the systems that 
are activated and suppressed in response to traumatic injury and initial resuscitation practices. Others have also reported associations between immune suppression, subsequent infection, and mortality. Taken together, it is likely that early immune suppression is central to the subsequent development of infection, organ failure, and death.

A number of mechanisms contribute to early postinjury changes in the immune system [4]. Catecholamines are one class of mediators thought to influence inflammation and may contribute to posttraumatic immune suppression [5, 6]. Endogenous epinephrine and norepinephrine are elevated after injury, and both agents may also be administered to treat shock. Circulating or elevated local concentrations of catecholamines may contribute to the altered immunity seen in critically injured patients $[5,7]$. There is evidence that vasopressor treatment during resuscitation is associated with mortality in severely injured patients, but less is known about its relationship with posttraumatic infection or sepsis [8].

We want to understand the mechanisms that contribute to catecholamine-induced immune suppression; specifically, those related to $\beta$-adrenergic agents. With this knowledge, it may be possible to intervene in ways that would mitigate immune suppression and the associated complications. The data presented here are in follow-up to our initial genome-wide interrogation of the effects of epinephrine on monocyte gene expression. In those experiments, we used a web-based entry tool (Ingenuity Systems Inc., Redwood City, CA, USA), to identify possible molecules and networks that might be important [9]. The results of this work implicated MKP-1 (DUSP-1) in the adrenergic influence on inflammation, and we followed this with a series of experiments to confirm the relationships between LPS and epinephrine exposure on monocyte MKP-1 and TNF- $\alpha$ gene expression [10]. The genome-wide expression results implicating MKP-1 (DUSP-1) are included in the online supplementary Tables S1 and S2 (for all online suppl. material, see www. karger.com/doi/10.1159/000486972).

In this report, we present the results of a series of experiments aimed to understand the role of MKP-1 and the related signaling pathways in catecholamine-induced immune suppression. We also examine the relationship between $\beta$-adrenergic vasopressor treatment (epinephrine or norepinephrine) in the first $96 \mathrm{~h}$ after severe injury and the subsequent development of nosocomial infections in order to better understand the clinical implications of immune suppression potentially related to adrenergic vasopressor treatment.

\section{Materials and Methods}

\section{Isolation of Peripheral Blood Monocytes}

Human peripheral blood mononuclear cells (PBMCs) from healthy subjects were isolated from fresh peripheral venous blood following Ficoll-Paque (Ficoll-Paque Puls; GE Healthcare, USA) centrifugation separation. The PBMCs were then added to tissue culture plates for $2 \mathrm{~h}$ at $37^{\circ} \mathrm{C}$ and nonadherent cells were gently washed off of the plate, leaving adherent cells behind, and media were replenished. Cells were exposed to $1 \mu \mathrm{M}$ epinephrine and/or $1 \mathrm{ng} / \mathrm{mL} \mathrm{LPS}$ or RPMI vehicle as control condition (for all experiments we used Escherichia coli LCD25; List Biologic Laboratories, Campbell, CA, USA). In these experiments and those that follow, cells were exposed to epinephrine (or vehicle) for $<5$ min prior to LPS exposure.

\section{Quantitative PCR}

Following RNA extraction, cDNA was reverse transcribed (Omniscript RT kit; Qiagen, USA) and MKP-1 and TNF- $\alpha$ mRNA levels were evaluated by qPCR via the SYBR green method (SYBR green master mix; Bio-Rad) with the following primers: MKP-1 primers: forward - GCCTTGCTTACCTTATGAGGAC, reverse GGGAGAGATGATGACTTCGCC; TNF- $\alpha$ primers: forward AGCCCATGTTGTAGCAAACC, reverse - TGAGGTACAGGCCCTCTGAT.

All qPCR analyses were adjusted to GAPDH. GAPDH primers: forward - GGGGAGCCAAAAGGGTCATCATCT, reverse GAGGGGCCATCCACAGTCTTCT.

\section{Western Blotting}

The THP-1 cell line (American Type Culture Collection [ATCC], Manassas, VA, USA) was used to test the effects of epinephrine on intracellular signaling pathways. THP-1 cells were differentiated with $100 \mathrm{~nm}$ vitamin $\mathrm{D}_{3}$ (Sigma Aldrich, St. Louis, MO, USA) for $48 \mathrm{~h}$ to enhance their ability to respond to LPS [11]. The cells were then treated with $1 \mu \mathrm{M}$ epinephrine and/or $1 \mathrm{ng} / \mathrm{mL}$ LPS and total cellular protein was isolated at a series of time points following stimulation. Total MKP-1 (Santa Cruz Biotechnology, Santa Cruz, CA, USA), phosphorylated MKP-1 (p-MKP-1) (Cell Signaling, Danvers, MA, USA), p-JNK (Promega, Madison, WI, USA), p-p38 (Cell Signaling), and total ERK (Santa Cruz Biotechnology) protein levels were then evaluated via Western blotting as described in the following paragraph.

Total protein was electrophoresed in a 10\% SDS-PAGE gel and transferred to a Hybond-ECL nitrocellulose membrane (Amersham Pharmacia Biotech, UK). The membrane was blocked for $1 \mathrm{~h}$ at room temperature with $5 \%$ bovine serum albumin (Sigma Aldrich) or 5\% milk (Nestlé, Solon, OH, USA) and then incubated with rabbit-derived antibodies directed against the active phosphorylated forms of MKP-1 (Cell Signaling), p-JNK (Promega), p-p38 (Cell Signaling), and nonphosophorylated total ERK2 (Santa Cruz Biotechnology) and MKP-1 (Santa Cruz Biotechnology) overnight at $4{ }^{\circ} \mathrm{C}$. The membrane was then incubated with goat anti-rabbit, horseradish peroxidase-conjugated antibody. The membrane was developed using the SuperSignal chemiluminescent substrate (Thermo Fisher Scientific, Rockford, IL, USA) and exposed on Kodak KAR-5 film (Eastman Kodak, Rochester, NY, USA). All gels were blotted with total ERK2 to confirm equal protein loading and data were analyzed after adjusting to ERK2 densitometry. Films were scanned and densitometry measured using ImageJ (National Institutes of Health, USA). 


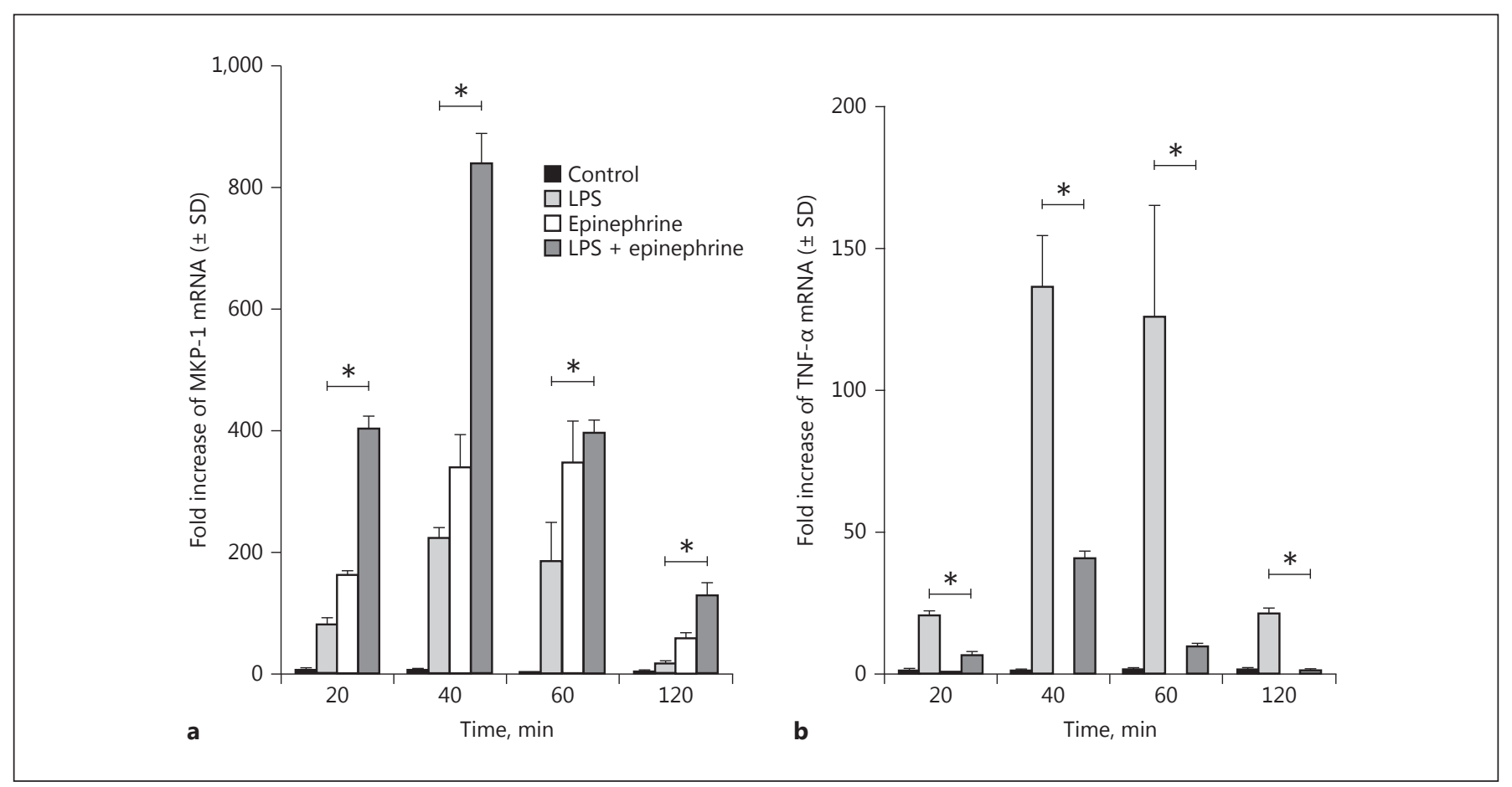

Fig. 1. Time course of MKP-1 and TNF- $\alpha$ gene expression. THP-1 cells were exposed to LPS, epinephrine, both together, or control conditions for $0,20,40,60$, and $120 \mathrm{~min}$. RNA was then extracted and cDNA quantified using rtPCR. All comparisons are made to time " 0 " which is not shown on the graph. Data were analyzed by two-way ANOVA using Bonferroni correction. a MKP-1 peaked at $40 \mathrm{~min}$ and to the greatest extent after combined exposure to

\section{RNA Inhibition}

Vitamin $\mathrm{D}_{3}$-differentiated ( $48 \mathrm{~h}, 100 \mathrm{nM}$ ) THP-1 cells were administered $50 \mathrm{nM}$ of noncoding or MKP-1 siRNA (Santa Cruz Biotechnology) in Ribojuice transfection reagent (EMD Millipore, Germany) for $24 \mathrm{~h}$. These cells were then exposed to $1 \mu \mathrm{M}$ epinephrine and/or $1 \mathrm{ng} / \mathrm{mL}$ LPS for $1 \mathrm{~h}$. MKP-1 and TNF- $\alpha$ expression levels were evaluated via qPCR.

\section{Clinical Cohort to Study the Relationship between}

$\beta$-Adrenergic Therapy and Infectious Complications after

Trauma

For this analysis, we studied subjects who had been enrolled into our single-center study of genetic factors associated with posttraumatic sepsis. This cohort has been presented in detail elsewhere and is summarized here $[12,13]$. Subjects were enlisted from a prospectively enrolled cohort of severely injured trauma patients admitted to the intensive care units at Harborview Medical Center in Seattle, WA, USA. Clinical data were obtained from two sources: (1) detailed information about injuries, including the Injury Severity Scale (ISS) score and the Abbreviated Injury Scale (AIS) score, were obtained from the institutional trauma registry, and (2) additional data were obtained from the electronic medical record. The University of Washington Human Subjects Division approved all study procedures. Sepsis and in-
LPS and epinephrine. The overall $p$ value was $0.020{ }^{*} p<0.05$, comparing epinephrine and LPS with LPS alone. $\mathbf{b}$ TNF- $\alpha$ expression was lower at each of the time points $(20,40,60$, and $120 \mathrm{~min})$ when cells were exposed to both LPS and epinephrine relative to LPS exposure alone. The overall $p$ value was $0.021 .^{*} p<0.05$, comparing epinephrine and LPS with LPS alone. $n=4$ for each experimental condition at each time point.

fectious complications were based upon data obtained from the electronic medical records. Bacteremia is defined as any positive culture from blood sampled from a peripheral vein or from a central venous catheter excluding Staphylococcus epidermidis, which we considered a contaminant. The diagnosis of ventilator-associated pneumonia at our institution generally requires quantitative cultures of samples obtained from the lower respiratory tract either by lavage or brushings. We followed the criteria established by Fagon et al. [14] in defining ventilator-associated pneumonia in our study.

\section{Data Presentation and Statistical Analyses}

Data were managed and analyzed using the following statistical programs: GraphPad Prism V.6 (USA), Stata/IC for Windows V21.1 (StataCorp, College Station, TX, USA), and SPSS for Windows V14.0 (USA). For analysis of the qPCR and cell signaling data, ANOVA with Bonferroni correction was used to adjust for multiple comparisons where appropriate. The Dunnett post hoc test was used when all treatment groups were compared to the control group. The clinical data were first analyzed using unadjusted comparisons between the subjects treated with $\beta$-adrenergic vasopressors and those who were not. Logistic regression analysis (forward stepwise) was used to adjust for multiple risk factors and confounding variables in order to determine the risk of infectious 
Fig. 2. MKP-1 and TNF- $\alpha$ gene expression in human peripheral blood monocytes. In order to confirm that THP-1 cells reflected what could be occurring in vivo, we isolated PBMCs from healthy adults and exposed these cells to the same experimental conditions for $40 \mathrm{~min}$. Data were analyzed by ANOVA. a Combined exposure induced the highest MKP-1 response, followed by LPS alone and then epinephrine alone. The overall $p$ value was $<0.0001$. $* p<0.05$, using Dunnett's post hoc adjustment. b TNF-a gene expression was lower in the cells exposed to both agents compared to LPS exposure $(9.8 \pm 3.1$ and $17 \pm$ 6.3 , respectively). ${ }^{*} p<0.05$, ANOVA with Bonferroni correction. The data displayed are based upon PBMCs isolated from 6 healthy subjects tested under each experimental condition.

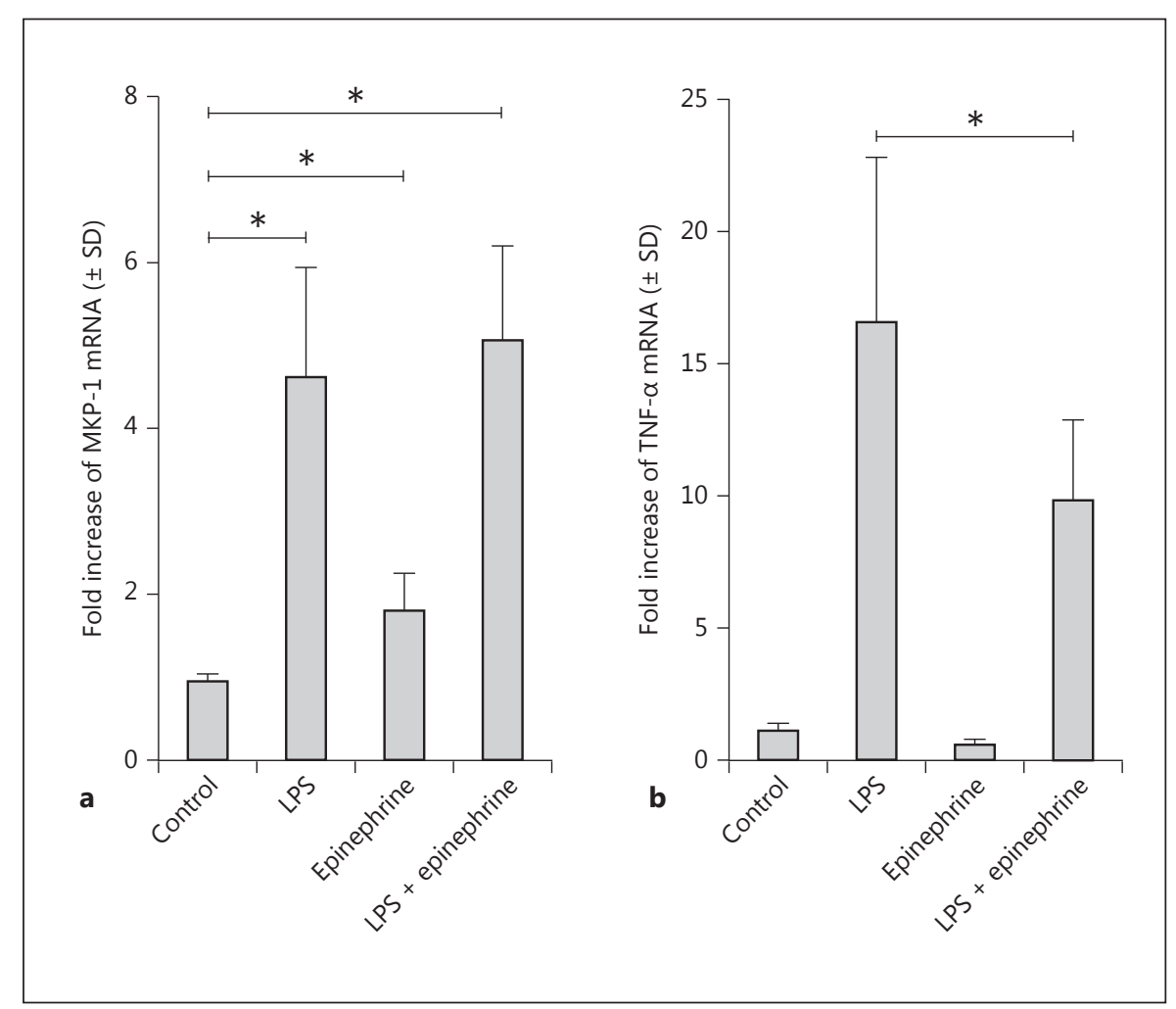

complications associated with vasopressor medication use in the first 3 days after injury. These data are presented as adjusted odds ratios (aOR) with 95\% confidence intervals (95\% CI) and the associated $p$ values.

\section{Results}

Epinephrine Decreases TNF- $\alpha$ Gene Transcription and Increases MKP-1 Gene Transcription

We wanted to confirm our previous genome-wide observation that MKP-1 gene transcription is increased by epinephrine. We first performed experiments using THP1 cells in order to clarify the time course of both MKP-1 and TNF- $\alpha$ gene transcription. Elevations in both MKP-1 (Fig. 1a) and TNF- $\alpha$ (Fig. 1b) were greatest at $40 \mathrm{~min}$. We then conducted experiments to determine whether human PBMCs demonstrated similar responses. At $40 \mathrm{~min}$, MKP-1 mRNA increased in response to LPS, epinephrine, or both (Fig. 2a). TNF-a gene transcription was lower in the presence of epinephrine pretreatment when compared with LPS treatment alone (Fig. 2b). In summary, the observations in human PBMCs were consistent with our observations in the THP-1 cells.
Epinephrine Pretreatment Increases MKP-1 and p-MKP-1, and Decreases MAPK Phosphorylation following Monocyte LPS Stimulation

MKP-1 regulates signaling by dephosphorylating mitogen-activated protein kinases (MAPKs). We wanted to know whether increased MKP-1 gene transcription leads to increased MKP-1 protein with a resultant decrease in MAPK phosphorylation. We examined the effect of epinephrine and LPS exposure on total MKP-1, p-JNK, and p-p38 kinase protein levels by Western blot analysis (Fig. 3). LPS alone had little effect on MKP-1 protein levels, whereas epinephrine increased MKP-1 protein, beginning at $30 \mathrm{~min}$ and increasing through $120 \mathrm{~min}$. The highest MKP-1 protein levels were seen at $60 \mathrm{~min}$ in cells exposed to both LPS and epinephrine (Fig. 3a). The levels of phosphorylated MKP-1 were more variable under all conditions than the other proteins, but this active form of the molecule was most elevated in response to epinephrine and LPS together, at the 60- and 120-min time points (Fig. 3b).

The changes in the phosphorylated forms of p38 and JNK corresponded to the aforementioned increased in MKP-1. In response to LPS, both p-p38 and p-JNK followed a pattern where levels peaked at $30 \mathrm{~min}$ and de- 

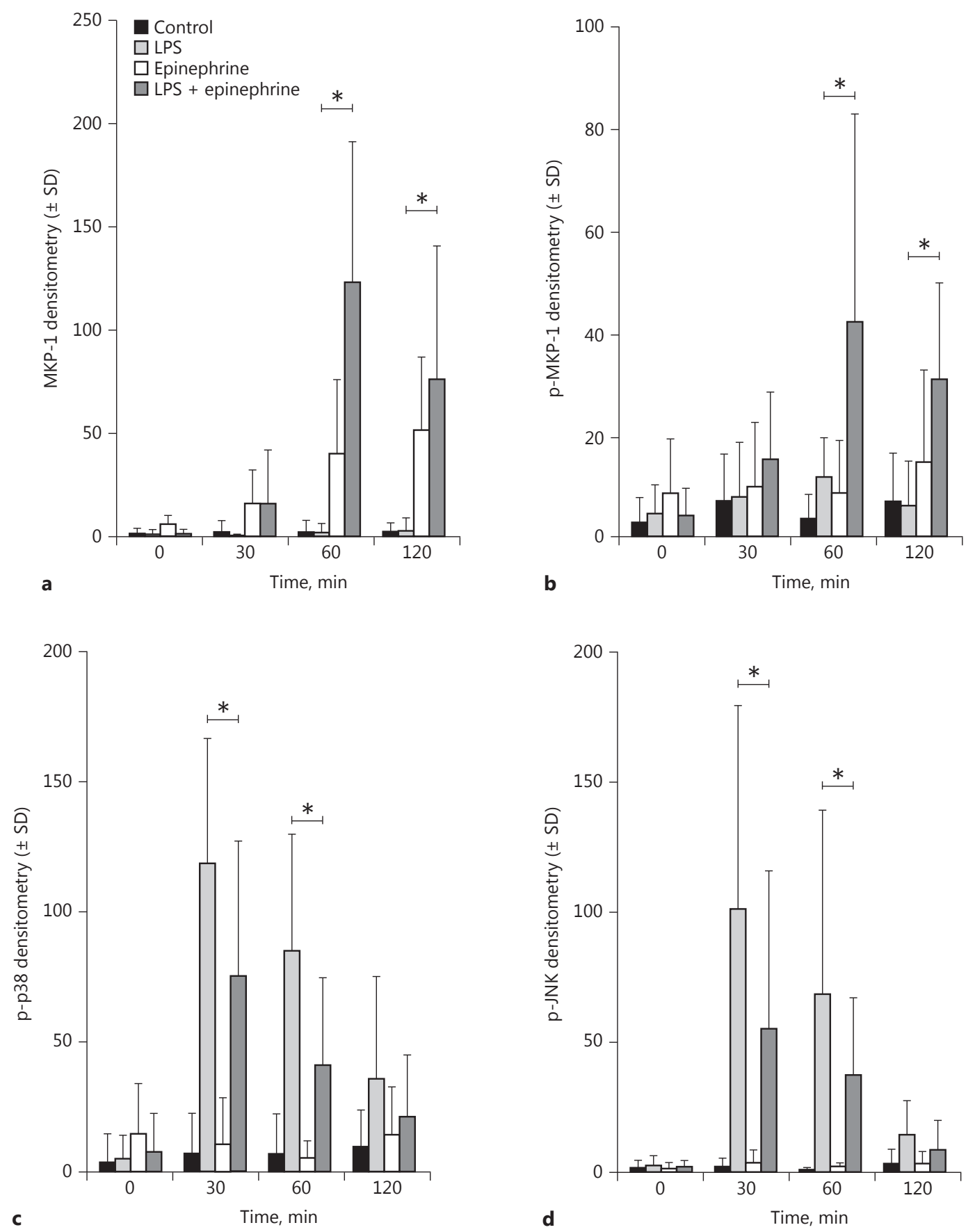

Fig. 3. MKP-1 protein and phosphorylated MAPKs levels. THP-1 cells were exposed to LPS and/or epinephrine and total cellular protein harvested after $0,30,60$, and $120 \mathrm{~min}$. Measurement of protein expression was determined by Western blot and adjusted for by ERK concentrations. a MKP-1 increased in response to epinephrine at $30 \mathrm{~min}$ and remained elevated throughout. a, b Both MKP-1 and p-MKP-1 increased greatest in response to a combina- tion of LPS and epinephrine, peaking at $60 \mathrm{~min}$. c, d Suppressed phosphorylation of p-p38 and p-JNK occurred in response to epinephrine stimulation. Exposure to epinephrine decreased levels of p-JNK and p38 at 30 and 60 min induced by LPS alone. ${ }^{*} p<0.05$, ANOVA adjusted with Bonferroni correction. e A representative Western blot. $n=5$ for each experimental condition at each time point with 3 technical replicates for each blot.

(Figure continued on next page.) 


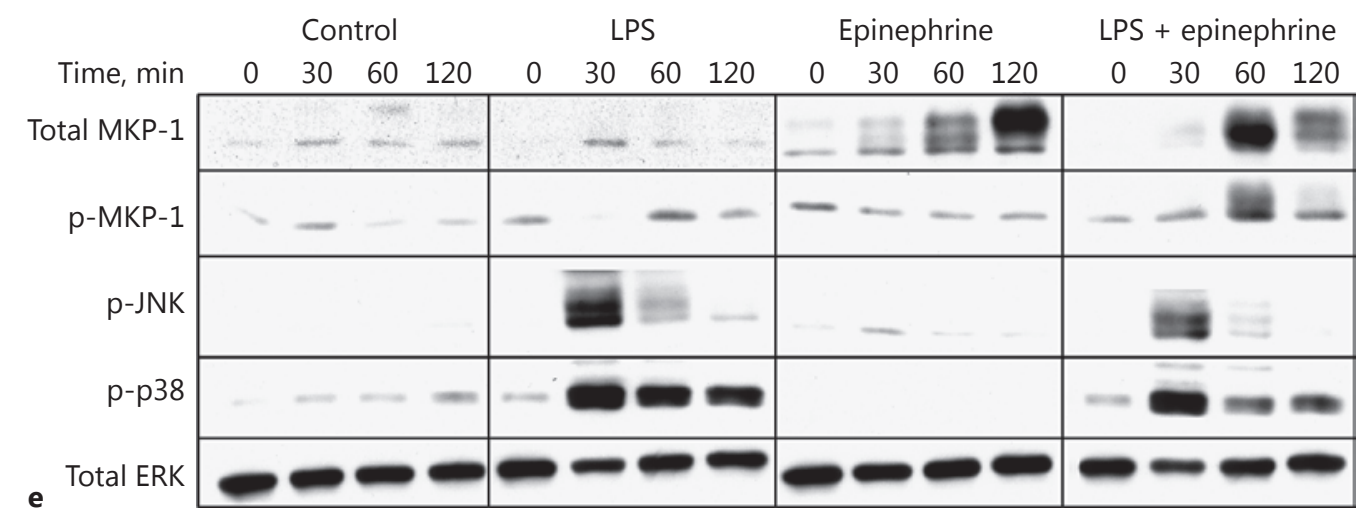

3

Fig. 4. MKP-1 and p-p38 protein expression in the presence of triptolide. a In the presence of triptolide, MKP-1 protein was suppressed to similar levels under all experimental conditions. b p-p38, in the presence of LPS, epinephrine, and triptolide was restored to levels similar to those of LPS without epinephrine $(100 \pm 35$ and $84 \pm 32$, respectively). ${ }^{*} p=0.42$, indicating inhibition of MKP-1 effects on MAPK signaling. $n=5$ for each experimental condition.

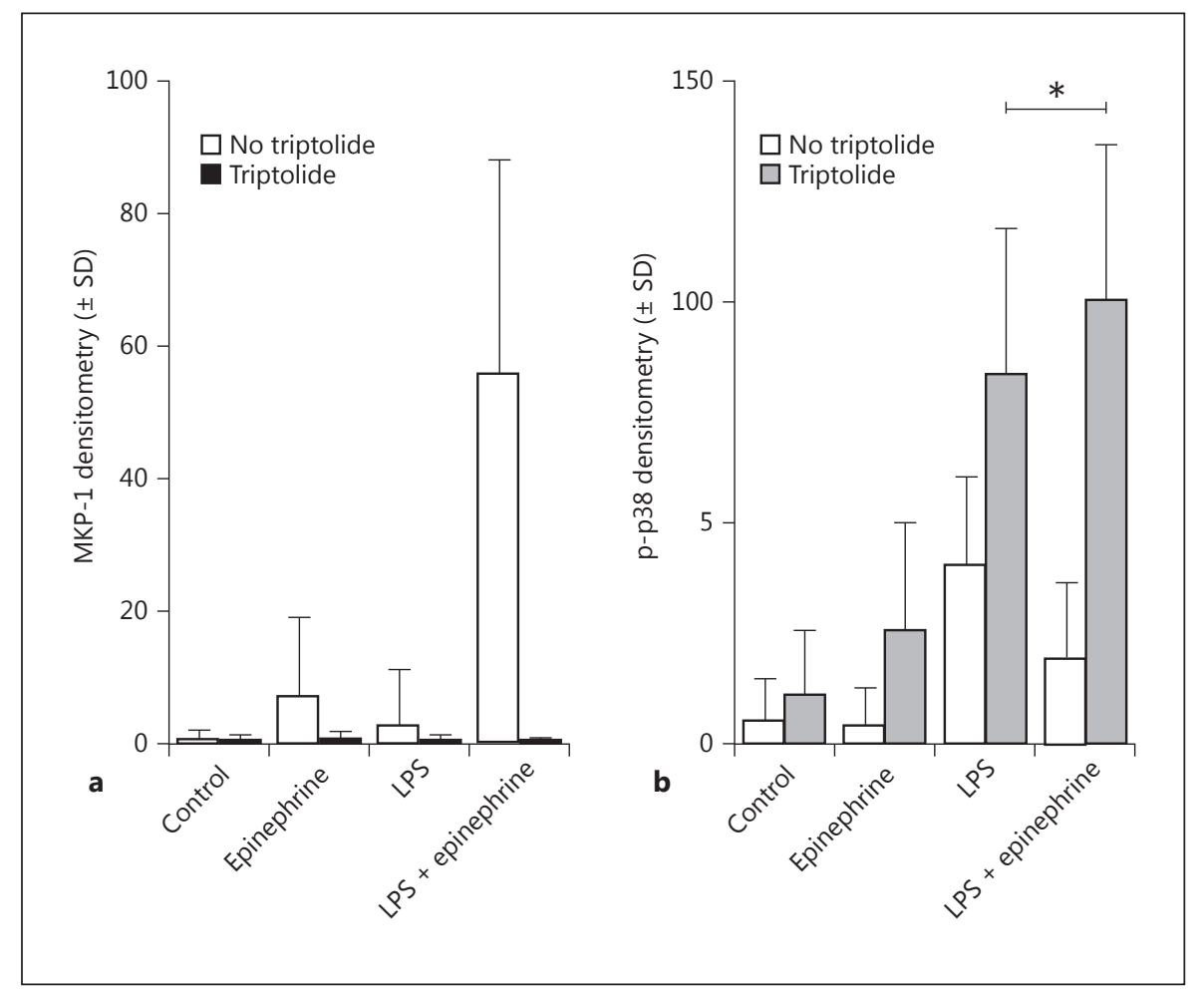

creased toward baseline levels by $120 \mathrm{~min}$. The effect of epinephrine on MAPK phosphorylation induced by LPS was evident at 30,60, and 120 min for both p38 and JNK but most marked at 30 and 60 min (Fig. 3c, d). In summary, epinephrine suppressed MAPK phosphorylation that was seen in response to LPS.
MKP-1 Inhibition Restores LPS-Induced p38

Phosphorylation and Partially Restores TNF- $\alpha$ Gene

Transcription

In order to determine whether dephosphorylation of MAPKs is a mechanism by which epinephrine might influence inflammatory signaling, MKP-1 activity was inhibited using triptolide. Triptolide, an extract from the herb Tripterygium wilfordii Hook F. used in traditional 

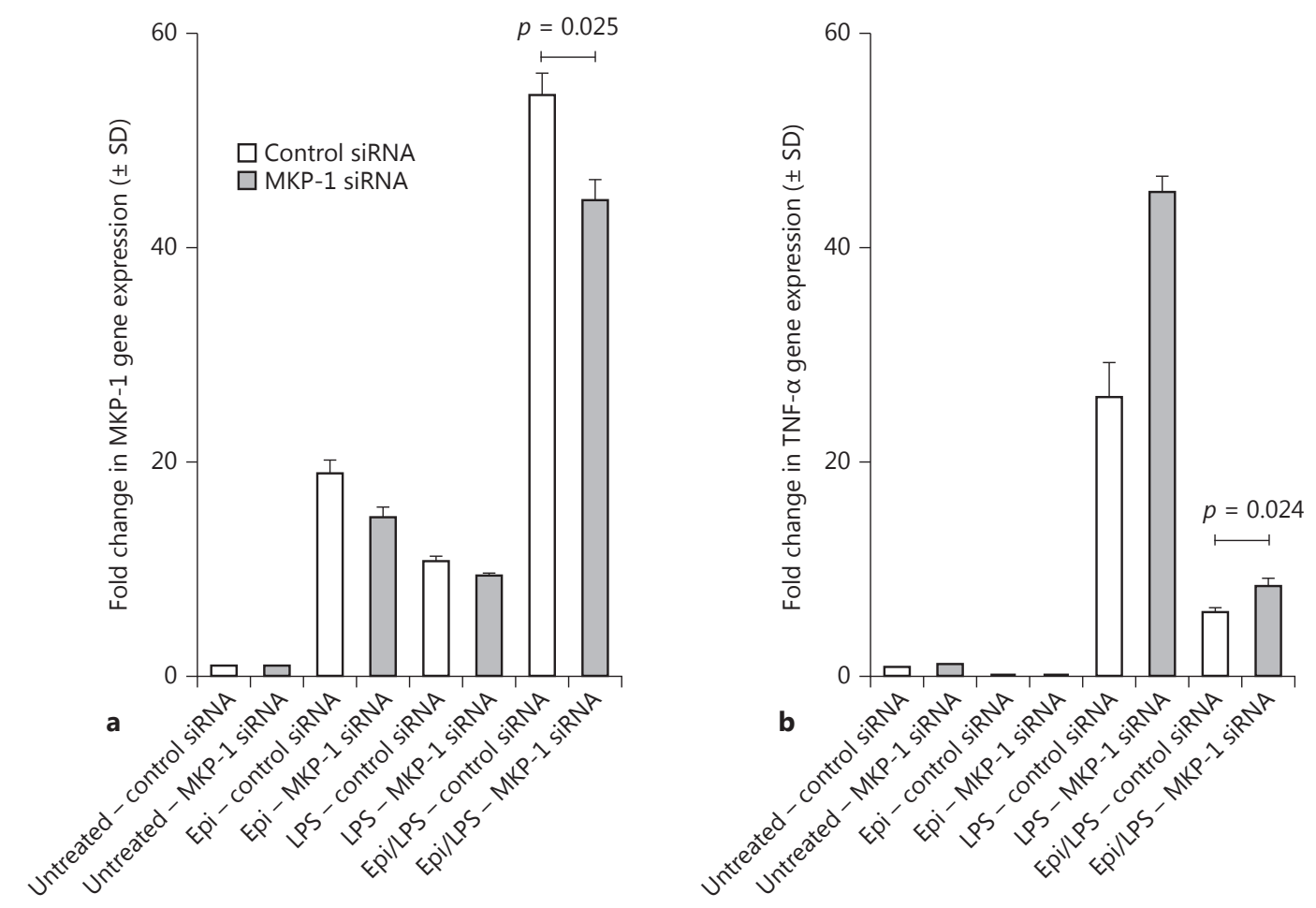

Fig. 5. Epinephrine-induced MKP-1 contributes to decreased TNF-a expression. We tested whether epinephrine-induced MKP1 expression directly contributes to the diminished TNF- $\alpha$ response using siRNA inhibition of MKP-1. Control and MKP-1 siRNA were administered to vitamin $\mathrm{D}_{3}$-differentiated THP-1 cells for $24 \mathrm{~h}$. Subsequently, $1 \mu \mathrm{M}$ epinephrine and/or $1 \mathrm{ng} / \mathrm{mL}$ LPS were administered to the siRNA-treated THP-1 monocytes and RNA was harvested $1 \mathrm{~h}$ after stimulation. a We observed that MKP-1 siRNA modestly inhibited MKP-1 mRNA expression in all

(herbal) treatments of rheumatoid arthritis, is known to be a potent MKP-1 inhibitor [15-19]. Triptolide pretreatment suppressed MKP-1 protein expression under all conditions (Fig. 4a). Exposure to triptolide, in the presence of epinephrine, restored phosphorylated p38 levels to those seen with LPS alone (Fig. 4b). Because triptolide blocks other inflammatory signaling molecules and pathways, including TNF- $\alpha$, it was not possible to determine whether its effects on MKP-1 inhibition restore TNF- $\alpha$ protein levels [20-23]. Therefore, these experiments indicate a role for $\beta$-adrenergic stimulation in MAPK dephosphorylation; however, they do not prove that this restores TNF- $a$ production.

In order to better clarify the role of MKP-1 in $\beta$ adrenergic suppression of TNF- $\alpha$, we used anti-MKP-1

$\beta$-Adrenergic Stimulation and Immune Suppression
3 stimulation conditions. The overall $p$ value by ANOVA was $<0.0001$ and the Bonferroni-corrected $p$ value of 0.025 is shown. b MKP-1 silencing partly rescued the epinephrine-induced suppression of mRNA when compared with control (noncoding) siRNA. The overall $p$ value by ANOVA was $<0.0001$. The two bars to the right indicate that gene silencing partially restored TNF- $\alpha$ gene expression ( $8 \pm 0.6$ and $11 \pm 1.4$; corrected $p$ value of 0.024 ). For the gene silencing experiments, $n=3$ for each experimental condition.

siRNA to knock down monocyte MKP-1. Following MKP-1 siRNA administration in THP-1 monocytes, we were able to partially inhibit MKP-1 gene expression induced by epinephrine, LPS, and epinephrine plus LPS compared with noncoding (control) siRNA administration (Fig. 5a). We also observed that MKP-1 siRNA knockdown resulted in rescued TNF- $\alpha$ mRNA expression when epinephrine was combined with LPS exposure (Fig. 5b).

\section{$\beta$-Adrenergic Vasopressor Treatment in Critically Injured Patients Was Associated with Ventilator- Associated Pneumonia and Bacteremia}

In a multicenter cohort of severely injured trauma victims, the use of vasopressor agents as part of their initial 
Table 1. Demographics, injury characteristics, and outcomes for the entire cohort $(n=1,645)$

\begin{tabular}{|c|c|}
\hline \multicolumn{2}{|l|}{ Demographics } \\
\hline Age, years & $40(1-52)$ \\
\hline \multicolumn{2}{|l|}{ Sex } \\
\hline Male & $1,189(72)$ \\
\hline Female & $456(28)$ \\
\hline \multicolumn{2}{|l|}{ Race/Ethnicity } \\
\hline Caucasian & $1,227(75)$ \\
\hline African-American & $101(6)$ \\
\hline Hispanic & $124(7)$ \\
\hline Asian & $71(4)$ \\
\hline American Indian & $36(2)$ \\
\hline Unknown & $86(5)$ \\
\hline \multicolumn{2}{|l|}{ Chronic comorbidities } \\
\hline Diabetes & $117(7)$ \\
\hline Cardiovascular & $419(26)$ \\
\hline Respiratory & $179(11)$ \\
\hline Hepatic & $102(6)$ \\
\hline Cancer & $59(4)$ \\
\hline \multicolumn{2}{|l|}{ Injury characteristics } \\
\hline Injury severity score & $33(25-75)$ \\
\hline Severe brain injury & $984(60)$ \\
\hline Severe thoracic injury & $977(60)$ \\
\hline Severe abdominal injury & $469(29)$ \\
\hline Severe lower extremity injury & $257(15)$ \\
\hline Severe upper extremity injury & $651(39)$ \\
\hline Severe spine injury & $533(32)$ \\
\hline \multicolumn{2}{|l|}{ Injury mechanism } \\
\hline Blunt & $1,507(91)$ \\
\hline Penetrating & $138(8)$ \\
\hline Initial base deficit $>6$ & $642(39)$ \\
\hline PRBC transfused, units & $4(1-8)$ \\
\hline Vasopressor treatment & $192(11)$ \\
\hline \multicolumn{2}{|l|}{ Operative procedures performed } \\
\hline Laparotomy & $311(19)$ \\
\hline Thoracotomy & $151(9)$ \\
\hline Fracture fixation & $888(54)$ \\
\hline \multicolumn{2}{|l|}{ Outcomes } \\
\hline Mortality & $215(13)$ \\
\hline ICU length of stay, days & $10(5-17)$ \\
\hline Hospital length of stay, days & $20(12-31)$ \\
\hline Duration of mechanical ventilation, days & $8(4-14)$ \\
\hline Ventilator-free days & $19(8-23)$ \\
\hline Ventilator-associated pneumonia & $557(34)$ \\
\hline Bacteremia & $261(16)$ \\
\hline Gram positive & $178(11)$ \\
\hline Gram negative & $98(6)$ \\
\hline
\end{tabular}

Continuous data are presented as medians (25-75th percentiles) and categorical data are indicated as $n$ (\%). Severe traumatic brain, thoracic, abdominal, and extremity injuries refer to the number of patients with abbreviated injury scores $\geq 3$ in the indicated body region. The entire cohort included 2,953 subjects, of whom 1,213 with $<3$ days of mechanical ventilation and 95 with burn injuries were excluded. PRBC, packed red blood cells; ICU, intensive care unit. resuscitation was associated with subsequent mortality [8]. If $\beta$-adrenergic stimulation suppresses immunity, it is reasonable to expect an increase in infectious complications in patients treated with $\beta$-adrenergic agents. Therefore, we examined whether infusion of either epinephrine or norepinephrine during the initial few days after injury (days $0-3$ ) was associated with subsequent nosocomial infection. We focused on ventilator-associated pneumonia (the most common infection) and bacteremia (representing failure of innate immune responses to localize an infection). Both of these are important complications of traumatic injury $[1,24]$. There were 1,645 subjects who received $\geq 3$ days of mechanical ventilation. A summary of their demographics, injury characteristics, and outcomes are shown in Table 1 . $\beta$-Adrenergic agent use was uncommon during the first 4 days after injury. A total of 192 subjects (12\%) received $\beta$-adrenergic agents at any point during days $0-3$. The 1 st postinjury day had the highest $\beta$-adrenergic use (132 subjects) and postinjury day 0 had the lowest use (56 subjects). Of those receiving $\beta$-adrenergic infusions, 125 received the infusion for less than $48 \mathrm{~h}$ and 67 subjects received more than $48 \mathrm{~h}$ of infusion. Demographic information, injury characteristics, and outcomes are shown in Table 2 for subjects according to whether they received $\beta$-adrenergic agents. Those who did were slightly older, had more severe shock, had higher injury severity scores and received more blood products than those who did not receive these agents. First, by unadjusted analyses, $\beta$-adrenergic treatment was associated with an increase in the incidence of both ventilator-associated pneumonia $(\mathrm{RR}=1.6 ; 95 \% \mathrm{CI}=1.3-1.9)$ and bacteremia $(\mathrm{RR}=$ $1.7 ; 95 \% \mathrm{CI}=1.4-2.1)$. Using logistic regression to adjust for other risk and potentially confounding factors, we observed that $\beta$-adrenergic agents were associated with an increased risk of both ventilator-associated pneumonia $(\mathrm{aOR}=1.9 ; 95 \% \mathrm{CI}=1.3-2.6)$ and bacteremia $(\mathrm{aOR}=1.5 ; 95 \% \mathrm{CI}=1.1-2.5)$. The results of these analyses are shown in Table 3.

Although logistic regression is meant to help adjust for the potential confounding effects of other factors on the outcomes of interest, differences between our two groups that led to the use of vasopressors might not be adequately captured in the available data that may also contribute to infection risk. Propensity score analysis has been used to help address this potential shortcoming $[25,26]$. We performed a propensity-matched analysis by first calculating the propensity for receiving early adrenergic vasopressors. We then matched subjects who received early vasopressors in a ratio of 1:2 to subjects who did not, who 
Table 2. Demographics, injury characteristics, and outcomes according to whether subjects received $\beta$-adrenergic agents

\begin{tabular}{|c|c|c|c|}
\hline & $\begin{array}{l}\beta \text {-Adrenergic } \\
\text { treatment } \\
(n=192)\end{array}$ & $\begin{array}{l}\text { No } \beta \text {-adrenergic } \\
\text { treatment } \\
(n=1,453)\end{array}$ & $p$ value \\
\hline \multicolumn{4}{|l|}{ Demographic and injury characteristics } \\
\hline Age, years & $40(24-58)$ & $37(23-52)$ & 0.04 \\
\hline Male & $149(78)$ & $1,040(72)$ & 0.08 \\
\hline APACHE II & $26(22-30)$ & $29(25-33)$ & $<0.0001$ \\
\hline Initial base deficit $\geq 6, \mathrm{mEq} / \mathrm{L}$ & $91(47)$ & $551(37)$ & 0.01 \\
\hline$\geq 6$ units PRBCs in first $24 \mathrm{~h}$ & $60(31)$ & $314(21)$ & 0.003 \\
\hline Injury severity score & $35(26-44)$ & $30(24-41)$ & $<0.0001$ \\
\hline Severe abdominal injury & $63(32)$ & $406(28)$ & 0.16 \\
\hline Severe thoracic injury & $117(61)$ & $860(59)$ & 0.64 \\
\hline Severe brain injury & $122(64)$ & $862(59)$ & 0.26 \\
\hline Severe spinal injury & $78(41)$ & $455(31)$ & 0.01 \\
\hline Severe extremity injury & $95(49)$ & $653(45)$ & 0.24 \\
\hline \multicolumn{4}{|l|}{ Outcomes } \\
\hline Ventilator-associated pneumonia & $99(52)$ & $458(32)$ & $<0.0001$ \\
\hline Bacteremia & $48(25)$ & $213(15)$ & $<0.0001$ \\
\hline Duration of mechanical ventilation, days & $14(7-23)$ & $7(4-13)$ & $<0.0001$ \\
\hline Ventilator-free days & $1(0-14)$ & $20(11-24)$ & $<0.0001$ \\
\hline Duration of ICU stay, days & $15(8-24)$ & $9(5-16)$ & $<0.0001$ \\
\hline Duration of hospital stay, days & $22(11-38)$ & $20(13-30)$ & 0.63 \\
\hline Mortality & $70(37)$ & $145(10)$ & $<0.0001$ \\
\hline
\end{tabular}

were within 0.05 probability. This resulted in 192 subjects being matched to 384 who were not treated with adrenergic agents. The OR was 2.2 (95\% CI: 1.5-3.2) for ventilator-associated pneumonia and 1.7 (95\% CI: 1.1-2.6) for bacteremia in the propensity-matched analyses. A summary of the propensity-matched analyses for bacteremia and ventilator-associated pneumonia is included in online supplementary Table S3.

Based upon the logistic regression analyses, the risk of nosocomial infection associated with $\beta$-adrenergic agents was comparable to the risk associated with large volume transfusion of red blood cells. This relationship was supported by the findings of the propensity-matched analysis. In summary, our data demonstrate a relationship between exogenous $\beta$-adrenergic drug use during the first 3 days after injury and subsequent bacteremia and ventilator-associated pneumonia, suggesting a potential immune-suppressive effect of these agents.

$\beta$-Adrenergic Stimulation and Immune Suppression

\section{Discussion}

Activation of the innate immune response occurs in response to traumatic injury and is part of what has been termed a "genomic storm" [27]. Sympathetic activation, leading to local and systemic release of adrenergic mediators, is an important component of this response and contributes in significant, yet incompletely understood, ways to the response to injury. Our observations help us understand the mechanisms underlying the influence of sympathetic activation and the clinical use of $\beta$-adrenergic medications on inflammatory signaling and on important clinical outcomes. We have shown that $\beta$-adrenergic stimulation suppresses intracellular inflammatory signaling pathways and that $\beta$-adrenergic agent infusion after trauma is associated with an increased incidence of ventilator-associated pneumonia and bacteremia.

Sympathetic activation is essential for the "fight or flight" response; however, it is also known to regulate the 
Table 3. Logistic regression analyses of factors associated with ventilator-associated pneumonia and bacteremia

\begin{tabular}{|c|c|c|c|}
\hline Risk factor & $\begin{array}{l}\text { Adjusted } \\
\text { odds ratio }\end{array}$ & $95 \%$ CI & $p$ value \\
\hline \multicolumn{4}{|c|}{ Ventilator-associated pneumonia } \\
\hline Vasopressor treatment & 1.9 & $1.3-2.6$ & $<0.0001$ \\
\hline Age & 1.007 & $1.001-1.012$ & 0.01 \\
\hline APACHE II & 1.02 & $1.01-1.04$ & $<0.0001$ \\
\hline Sex & 0.78 & $0.61-0.99$ & 0.05 \\
\hline$\geq 6$ units $\mathrm{PRBC}$ in $24 \mathrm{~h}$ & 1.9 & $1.5-2.5$ & $<0.0001$ \\
\hline \multicolumn{4}{|l|}{ Bacteremia } \\
\hline Vasopressor treatment & 1.5 & $1.1-2.3$ & 0.02 \\
\hline Injury severity score & 1.01 & $1.001-1.02$ & 0.038 \\
\hline APACHE II & 1.02 & $1.001-1.043$ & 0.04 \\
\hline$\geq 6$ units PRBC in $24 \mathrm{~h}$ & 2.0 & $1.5-2.7$ & $<0.0001$ \\
\hline Severe brain injury & 0.7 & $0.5-0.88$ & 0.005 \\
\hline
\end{tabular}

Results of forward stepwise logistic regression models for each of ventilator-associated pneumonia and bacteremia. Vasopressor treatment is defined as any $\beta$-adrenergic agent administered during the first $72 \mathrm{~h}$ after injury. Severe brain injury is defined as a head abbreviated injury score $\geq 3$. Injury severity score and APACHE II were included as continuous variables. APACHE II, acute physiology and chronic health evaluation II; PRBC, packed red blood cells.

function of many immune cell types, including various lymphocyte, monocyte, and granulocyte populations. van der Poll et al. [5] demonstrated that $\beta$-adrenergic stimulation alters monocyte cytokine responses to endotoxin. They observed that in vivo $\beta$-adrenergic stimulation altered the mononuclear cell cytokine and inflammatory profiles and posited that these changes may occur in critically ill patients with sepsis $[6,7]$. However, they did not explore the potential mechanisms involved.

The mechanisms of the effect of adrenergic suppression of innate immune responses are likely multiple. We chose to focus on MKP-1 based upon our genome-wide gene expression data and observations by others supporting a role for $\beta$-adrenergic modulation of MKP-1 gene transcription [28-30].

There are a number of limitations of our data and observations related to the experimental and clinical observations. These are discussed here and will need to be addressed in future studies. First, our RNA inhibition experiments were only partially successful in knocking down MKP-1 and therefore were only partially able to restore TNF- $\alpha$ gene expression. However, it is likely that even full MKP-1 inhibition will not completely restore TNF- $\alpha$ or other gene transcription levels given that other mechanisms and pathways are doubtless involved. Nevertheless, it is possible that we simply were not able to achieve full gene inhibition with our methods. Determining the role of these competing hypotheses requires additional studies. It is also important to re-emphasize that our experimental observations relied primarily on data generated using the THP-1 cell line which may differ in important ways from in vivo responses of human circulating and tissue immune cells.

Our observation of an association between early norepinephrine or epinephrine infusion and subsequent nosocomial infection supports the notion that these agents have clinically relevant immune-suppressive actions, but does not prove this definitively. Subjects who received these agents were more ill than those who did not and it is not possible to address and control for all the unmeasured factors that were associated with their use and with subsequent nosocomial infections. Alternatively, the effect of vasopressors on infection risk may be completely unrelated to immune suppression. For example, it is possible that vasopressors contribute to splanchnic vasoconstriction, increasing intestinal bacterial translocation, and in this way place the patient at greater risk of subsequent infection. Neither of our multivariate statistical methods can definitively rule out the possibility of such alternate mechanisms.

This limitation is important to acknowledge but should not invalidate our interpretation, which is not different to that in other observational studies of critically ill patients. For example, initial studies observing a relationship between a low plasma to red blood cell transfusion ratio in patients receiving massive transfusion was clearly confounded by the sicker patients receiving relatively more units of red blood cells [31, 32]. Nevertheless, the importance of a balanced approach to transfusion eventually emerged and the initial observations were central to the development of prospective observational studies and clinical trials.

We included both norepinephrine and epinephrine as the adrenergic agents of potential importance as they both have $\beta$-adrenergic actions. It is likely that both of these agents have similar effects in immune cells that are mediated via the $\beta 2$ receptor and cyclic AMP intracellular signaling pathways. We reported on the effects of epinephrine as the $\beta$-agonist in our experiments; however, others have demonstrated similar effects on immune cell function with norepinephrine and the pure $\beta$-adrenergic agonist, isoproterenol.

Our experimental model does not capture all the complexity of the posttraumatic state. However, it is reason- 
able to consider that circulating and resident immune cells exposed to $\beta$-adrenergic agents at relatively high levels, as seen with infusion, develop immune suppression, establishing the groundwork for subsequent infection. There are data to support this notion. First, we know that a subgroup of patients who develop bacteremia after trauma have evidence of early suppression of innate immunity [1]. We also know that patients who develop persistent immune suppression after trauma have defects in innate and adaptive immunity beginning early after injury [33]. Our data here raise the possibility that $\beta$-adrenergic stimulation and activation of the cyclic AMP pathway play a role in this clinical trajectory.

MKP-1 activation is likely not the sole mechanism whereby adrenergic stimulation might alter immunity, nor is it definite that the changes we induced and observed in PBMCs are directly related to the nosocomial infections we observed in our cohort of trauma patients. Drawing this connection is premature. However, now that we have at least one cellular mechanism to study, we can look in more detail at the immune cells in critically ill patients and how they respond to adrenergic agents and inhibitors.

There are alternative vasopressor agents that could be used in the resuscitation of trauma and other critically ill patients. Vasopressin, for example, is in wide clinical use. However, whether it or other nonadrenergic agents improve outcomes over adrenergic drugs is not certain [34]. Vasopressin also signals through a G-protein-coupled receptor and activates cyclic AMP. Therefore, its effects on immune signaling, including induction of MKP-1 gene transcription, may not differ from $\beta$-adrenergic agents. Nevertheless, studies aimed to determine its effect on inflammatory signaling are warranted. $\alpha$-Adrenergic agonists are also potentially useful, but generally have been limited to patients with neurogenic shock.

Alternatively, $\beta$-adrenergic inhibitors could be used once shock has resolved and the patient has stabilized. The use of $\beta$-blockers has been examined in a number of studies of critically ill patients. Burn injury patients seem to derive the greatest benefit from $\beta$-adrenergic inhibition, primarily through a more rapid reversal of the effects of the hypermetabolism associated with burn injury $[35,36]$. There is also some evidence indicating that $\beta$-adrenergic inhibition can restore monocyte immune function and may reduce susceptibility to infection after burn injury [37], but we can only speculate on this possibility. It is possible that the immune-suppressive effects of adrenergic stimulation are established and will not be completely reversible by subsequent $\beta$-adrenergic inhibi- tor treatment. A prospective study aimed at testing the effects of $\beta$-adrenergic inhibition on innate immune function is warranted and is perhaps the best way to determine the importance of $\beta$-adrenergic stimulation on immune function.

Finally, our clinical observations only address the effects of exogenous $\beta$-adrenergic agent infusion and not the potential effects of the endogenous release of both epinephrine and norepinephrine as part of the stress response. It is possible that endogenous epinephrine release might influence subsequent immunity and patients who do not receive exogenous treatment will also benefit from $\beta$-adrenergic inhibition.

In summary, our data suggest a role for MKP-1 in the catecholamine-induced suppression of innate immunity. Given the use of catecholamines in critically ill patients, and the association with infectious complications that we observed in our traumatized subjects, it will be important to determine ways to reduce their use and inhibit their deleterious effects.

\section{Disclosure Statement}

The authors have no conflicts of interest relevant to this paper.

\section{Funding Sources}

This work was supported by NIGMS grants R01 GM066946 and T32 GM007037 and by the American Association for the Surgery of Trauma research and education foundation scholarship award.

\section{Author Contributions}

Nicholas J. Shubin: study design, conduct of experiments, data collection and analysis, and drafting of the manuscript. Tam N. Pham: study design, data analysis, and critical review of the manuscript. Kristan Lea Staudenmayer: literature reviews, study design, conduct of experiments, data collection and analysis, and critical review of the manuscript. Brodie A. Parent: data analysis and critical review of the manuscript. Qian Qiu: data analysis and critical review of the manuscript. Grant E. O'Keefe: literature review, study design, data collection and analysis, and drafting and review of the manuscript. 


\section{References}

-1 Thompson CM, Park CH, Maier RV, O’Keefe GE: Traumatic injury, early gene expression, and gram-negative bacteremia. Crit Care Med 2014;42:1397-1405.

>2 Singer M, Deutschman CS, Seymour CW, Shankar-Hari M, Annane D, Bauer M, Bellomo R, Bernard GR, Chiche JD, Coopersmith CM, Hotchkiss RS, Levy MM, Marshall JC, Martin GS, Opal SM, Rubenfeld GD, van der Poll T, Vincent JL, Angus DC: The Third International Consensus Definitions for Sepsis and Septic Shock (Sepsis-3). JAMA 2016;315: 801-810.

$\checkmark 3$ Mouncey PR, Osborn TM, Power GS, Harrison DA, Sadique MZ, Grieve RD, Jahan R, Tan JC, Harvey SE, Bell D, Bion JF, Coats TJ, Singer M, Young JD, Rowan KM: Protocolised Management in Sepsis (ProMISe): a multicentre randomised controlled trial of the clinical effectiveness and cost-effectiveness of early, goal-directed, protocolised resuscitation for emerging septic shock. Health Technol Assess 2015;19:1-150.

$\checkmark 4$ Minei JP, Cuschieri J, Sperry J, Moore EE, West MA, Harbrecht BG, O’Keefe GE, Cohen MJ, Moldawer LL, Tompkins RG, Maier RV; Inflammation and the Host Response to Injury Collaborative Research Program: The changing pattern and implications of multiple organ failure after blunt injury with hemorrhagic shock. Crit Care Med 2012;40:11291135 .

5 van der Poll T, Coyle SM, Barbosa K, Braxton CC, Lowry SF: Epinephrine inhibits tumor necrosis factor-alpha and potentiates interleukin 10 production during human endotoxemia. J Clin Invest 1996;97:713-719.

-6 Guirao X, Kumar A, Katz J, Smith M, Lin E, Keogh C, Calvano SE, Lowry SF: Catecholamines increase monocyte TNF receptors and inhibit TNF through beta 2-adrenoreceptor activation. Am J Physiol 1997;273:E1203E1208.

7 van der Poll T, Lowry SF: Epinephrine inhibits endotoxin-induced IL-1 beta production: roles of tumor necrosis factor-alpha and IL10. Am J Physiol 1997;273:R1885-R1890.

-8 Sperry JL, Minei JP, Frankel HL, West MA, Harbrecht BG, Moore EE, Maier RV, Nirula R: Early use of vasopressors after injury: caution before constriction. J Trauma 2008;64: 9-14.

9 Calvano SE, Xiao W, Richards DR, Felciano RM, Baker HV, Cho RJ, Chen RO, Brownstein BH, Cobb JP, Tschoeke SK, Miller-Graziano C, Moldawer LL, Mindrinos MN, Davis RW, Tompkins RG, Lowry SF: A networkbased analysis of systemic inflammation in humans. Nature 2005;437:1032-1037.

10 Lee J, Jelacic S, Junker C, O’Keefe G: Epinephrine increases MKP-1 in LPS-stimulated THP-1 cells. Shock 2006;25:81.
11 Rivera-Chavez FA, Wheeler H, Lindberg G, Munford RS, O'Keefe GE: Regional and systemic cytokine responses to acute inflammation of the vermiform appendix. Ann Surg 2003;237:408-416.

12 Thompson CM, Holden TD, Rona G, Laxmanan B, Black RA, O'Keefe GE, Wurfel MM: Toll-like receptor 1 polymorphisms and associated outcomes in sepsis after traumatic injury: a candidate gene association study. Ann Surg 2014;259:179-185.

13 Shalhub S, Junker CE, Imahara SD, Mindrinos MN, Dissanaike S, O’Keefe GE: Variation in the TLR4 gene influences the risk of organ failure and shock posttrauma: a cohort study. J Trauma 2009;66:115-122; discussion 122113.

14 Fagon JY, Chastre J, Wolff M, Gervais C, Parer-Aubas S, Stéphan F, Similowski T, Mercat A, Diehl JL, Sollet JP, Tenaillon A: Invasive and noninvasive strategies for management of suspected ventilator-associated pneumonia. A randomized trial. Ann Intern Med 2000;132:621-630.

15 Shepherd EG, Zhao Q, Welty SE, Hansen TN, Smith CV, Liu Y: The function of mitogenactivated protein kinase phosphatase-1 in peptidoglycan-stimulated macrophages. J Biol Chem 2004;279:54023-54031.

16 Chen P, Li J, Barnes J, Kokkonen GC, Lee JC, Liu Y: Restraint of proinflammatory cytokine biosynthesis by mitogen-activated protein kinase phosphatase- 1 in lipopolysaccharidestimulated macrophages. J Immunol 2002; 169:6408-6416.

17 Chen BJ: Triptolide, a novel immunosuppressive and anti-inflammatory agent purified from a Chinese herb Tripterygium wilfordii Hook F. Leuk Lymphoma 2001;42:253-265.

18 Lee KY, Chang W, Qiu D, Kao PN, Rosen GD: PG490 (triptolide) cooperates with tumor necrosis factor-alpha to induce apoptosis in tumor cells. J Biol Chem 1999;274:1345113455.

19 Qiu D, Zhao G, Aoki Y, Shi L, Uyei A, Nazarian S, Ng JC, Kao PN: Immunosuppressant PG490 (triptolide) inhibits T-cell interleukin-2 expression at the level of purine-box/ nuclear factor of activated T-cells and NF- $\kappa \mathrm{B}$ transcriptional activation. J Biol Chem 1999; 274:13443-13450.

20 Matta R, Wang X, Ge H, Ray W, Nelin LD, Liu Y: Triptolide induces anti-inflammatory cellular responses. Am J Transl Res 2009; 1:267282.

21 Zhao G, Vaszar LT, Qiu D, Shi L, Kao PN: Anti-inflammatory effects of triptolide in human bronchial epithelial cells. Am J Physiol Lung Cell Mol Physiol 2000;279:L958-L966.
22 Zhou HF, Niu DB, Xue B, Li FQ, Liu XY, He QH, Wang XH, Wang XM: Triptolide inhibits TNF-alpha, IL-1 beta and NO production in primary microglial cultures. Neuroreport 2003;14:1091-1095.

23 Jiang XH, Wong BC, Lin MC, Zhu GH, Kung HF, Jiang SH, Yang D, Lam SK: Functional p53 is required for triptolide-induced apoptosis and AP- 1 and nuclear factor $-\kappa \mathrm{B}$ activation in gastric cancer cells. Oncogene 2001;20: 8009-8018.

24 Melsen WG, Rovers MM, Groenwold RH, Bergmans DC, Camus C, Bauer TT, Hanisch EW, Klarin B, Koeman M, Krueger WA, Lacherade JC, Lorente L, Memish ZA, Morrow LE, Nardi G, van Nieuwenhoven CA, O’Keefe GE, Nakos G, Scannapieco FA, Seguin $\mathrm{P}$, Staudinger T, Topeli A, Ferrer M, Bonten MJ: Attributable mortality of ventilator-associated pneumonia: a meta-analysis of individual patient data from randomised prevention studies. Lancet Infect Dis 2013;13: 665-671.

25 Haukoos JS, Lewis RJ: The propensity score. JAMA 2015;314:1637-1638.

26 Lee J, An JN, Hwang JH, Kim YL, Kang SW, Yang CW, Kim NH, Oh YK, Lim CS, Kim YS, Lee JP: Effect of dialysis initiation timing on clinical outcomes: a propensity-matched analysis of a prospective cohort study in Korea. PLoS One 2014;9:e105532.

27 Xiao W, Mindrinos MN, Seok J, Cuschieri J, Cuenca AG, Gao H, Hayden DL, Hennessy L, Moore EE, Minei JP, Bankey PE, Johnson JL, Sperry J, Nathens AB, Billiar TR, West MA, Brownstein $\mathrm{BH}$, Mason $\mathrm{PH}$, Baker HV, Finnerty CC, Jeschke MG, López MC, Klein MB, Gamelli RL, Gibran NS, Arnoldo B, Xu W, Zhang Y, Calvano SE, McDonald-Smith GP, Schoenfeld DA, Storey JD, Cobb JP, Warren HS, Moldawer LL, Herndon DN, Lowry SF, Maier RV, Davis RW, Tompkins RG; Inflammation and Host Response to Injury Large-Scale Collaborative Research Program: A genomic storm in critically injured humans. J Exp Med 2011;208:2581-2590.

-28 Chansard M, Iwahana E, Liang J, Fukuhara C: Regulation of cAMP-induced arylalkylamine N-acetyltransferase, Period1, and MKP-1 gene expression by mitogen-activated protein kinases in the rat pineal gland. Brain Res Mol Brain Res 2005;139:333-340.

29 Price DM, Terriff DL, Chik CL, Ho AK: The role of protein turnover in regulating $\mathrm{MKP}-1$ levels in rat pinealocytes. Mol Cell Endocrinol 2007;263:134-141.

30 Usmani OS, Ito K, Maneechotesuwan K, Ito M, Johnson M, Barnes PJ, Adcock IM: Glucocorticoid receptor nuclear translocation in airway cells after inhaled combination therapy. Am J Respir Crit Care Med 2005;172:704712 . 
31 Holcomb JB, Pati S: Optimal trauma resuscitation with plasma as the primary resuscitative fluid: the surgeon's perspective. Hematology Am Soc Hematol Educ Program 2013; 2013:656-659.

32 Holcomb JB, del Junco DJ, Fox EE, Wade CE, Cohen MJ, Schreiber MA, Alarcon LH, Bai Y, Brasel KJ, Bulger EM, Cotton BA, Matijevic N, Muskat P, Myers JG, Phelan HA, White CE, Zhang J, Rahbar MH; PROMMTT Study Group: The prospective, observational, multicenter, major trauma transfusion (PROMMTT) study: comparative effectiveness of a time-varying treatment with competing risks. JAMA Surg 2013;148:127-136.
33 Mira JC, Gentile LF, Mathias BJ, Efron PA, Brakenridge SC, Mohr AM, Moore FA, Moldawer LL: Sepsis pathophysiology, chronic critical illness, and persistent inflammation-immunosuppression and catabolism syndrome. Crit Care Med 2017;45:253-262.

34 Belletti A, Musu M, Silvetti S, Saleh O, Pasin L, Monaco F, Hajjar LA, Fominskiy E, Finco G, Zangrillo A, Landoni G: Non-adrenergic vasopressors in patients with or at risk for vasodilatory shock. a systematic review and meta-analysis of randomized trials. PLoS One 2015;10:e142605.
5 Herndon DN, Rodriguez NA, Diaz EC, Hegde S, Jennings K, Mlcak RP, Suri JS, Lee JO, Williams FN, Meyer W, Suman OE, Barrow RE, Jeschke MG, Finnerty CC: Long-term propranolol use in severely burned pediatric patients: a randomized controlled study. Ann Surg 2012;256:402-411.

36 Norbury WB, Jeschke MG, Herndon DN: Metabolism modulators in sepsis: propranolol. Crit Care Med 2007;35:S616-S620.

37 Kobayashi M, Jeschke MG, Asai A, Kogiso M, Yoshida S, Herndon DN, Suzuki F: Propranolol as a modulator of M2b monocytes in severely burned patients. J Leukoc Biol 2011;89: 797-803. 